\title{
Boris Uspenskij on history, linguistics and semiotics
}

\author{
Ekaterina Velmezova, Kalevi Kull \\ Centre for Linguistics and Language Sciences, University of Lausanne \\ Anthropole, $\mathrm{CH}-1015$ Lausanne, Switzerland \\ e-mail: ekaterina.velmezova@unil.ch \\ Department of Semiotics, University of Tartu \\ Jakobi 2, 51014 Tartu, Estonia \\ e-mail: kalevi.kull@ut.ee
}

\begin{abstract}
The two interviews with Boris Uspenskij on history and the contemporary state of linguistics and semiotics discuss the necessity to elaborate a common terminology in semiotics, at the same time speaking about perspectives for interdisciplinary research, various research models, and the possibilities to produce proof in the humanities. Commenting upon some of his own works, in particular on Ego loquens (2007), Boris Uspenskij reflects upon the crucial events of his academic life and on contacts with his colleagues, emphasizing the importance of friendship with Roman Jakobson and Juri Lotman.
\end{abstract}

Keywords: history of semiotics; Louis Hjelmslev; Roman Jakobson; Juri Lotman; TartuMoscow School; sign typology

Boris Andreevich Uspenskij (born in 1937), linguist and semiotician from Moscow, has been one of the leading figures of the Tartu Summer Schools of Semiotics, and a prominent co-author of Juri Lotman. ${ }^{1}$ Here, we publish the texts of two conversations

1 Boris Uspenskij's selection of works has been published in two editions of his Selected Works (first edition: Uspenskij 1994a and 1994b, also 1995; the 2nd enlarged edition: 1996a, 1996b, 1997). His bibliography is presented in F. Uspenskij 2008: 7-65, and in Boyko 2017. About his work in general, see Lepik 2013; Guan 2012. The issue 11(2/3) of the journal Russian Linguistics (1987) was dedicated to the 50th birthday of Boris Uspenskij, and two other festschrifts Miscellanea slavica (F. Uspenskij 2008) and Forma formans (Bertolissi, Salvatore 2010) were published for his 70th birthday. For some earlier published interviews with Boris Uspenskij see Podgorzec 1978 [1977]; Salupere 2002; Mazzali-Lurati 2014; Trunin 2016. 
with him that took place in 2011 and 2012 and have been merged into a two-part interview. The first conversation took place on 25 August, 2011, at the end of the Tartu Summer School of Semiotics Semiotic Modelling, held at Palmse, Estonia, on 22-26 August, 2011, that was the eighth Tartu Summer School of Semiotics according to our count ${ }^{2}$. That particular Summer School started a new period in this series. Boris Uspenskij had attended the first six schools and in 2011, in order to renew the tradition, we invited several participants of the Summer Schools of the 1960s Boris Uspenskij, Tatyana Tsivyan and Boris Egorov ${ }^{3}$ - to take part in the event, and devoted the whole of the first day to their talks. Our questions to Uspenskij focused on his views on semiotics and on his work in this field. For the second part of the interview, we visited him at his home in Rome on May 27, 2012. Most of the additional questions asked at the time were based on his book Ego Loquens: Language and the Communicative Space (2007). ${ }^{4}$

\section{Part I. On semiotics and linguistics, their history and state of the art today}

- Boris Andreevich, what would you say about the state of modern semiotics in general?

- Unfortunately, theoretical semiotics is not moving forward. In my opinion, the situation is very bad, because there is no progress in semiotics.

- How long has this been the case, in your opinion?

- I'm afraid that it began already in the 1960s-1970s. From that time on, there has been no progress in this field and no evolution.

- What are the reasons of this situation, to your mind? What are the major problems of modern semiotics?

2 The first school took place in 1964 in Kääriku; the second - in 1966 (Kääriku); the third in 1968 (Kääriku); the forth - in 1970 (Tartu); the fifth - in 1974 (Tartu); the sixth - in 1986 (Kääriku); the seventh - in 1995 (Saarjärve); the eighth - in 2011 (Palmse); the ninth - in 2013 (Kääriku); the tenth - in 2015 (Tartu); the eleventh - in 2017 (Tartu).

3 See Pärn 2012; Kull et al. 2011: 323-326.

4 The conversations were held in Russian and recorded; the Russian transcript and its translation into English have been approved by Boris Uspenskij. The Russian text was translated into English by Ekaterina Velmezova; all footnotes have been composed by Kalevi Kull and Ekaterina Velmezova. See also our earlier interview with Vyacheslav Ivanov (Velmezova, Kull 2011). 
- It seems to me that, in semiotics, basic concepts have not been defined; there is no unity of methods. The words 'semiotics' and 'sign' seem so clear that people can use them without any kind of definition - just because everything looks obvious. Actually, however, semioticians very often use different metalanguages, which leads to the absence of real communication between them.

- Do you suppose that modern semiotics needs one, more or less generally accepted metalanguage?

- I think so, yes. At least, a basic language of general notions.

- Indeed, there is a whole number of schools using various terminologies...

- Exactly. And I don't know how to go forward in this direction unless there is one single meta-language. I am not sure that it is possible to find something in common between these schools. From time to time, international congresses on semiotics are organized, and this creates an impression that their participants are united by common subjects and common research approaches, that they do the same thing, but it is not the case. It is a bad sign which is indicative of a decline of this science. I would compare this process with that of a language destruction. We know how a natural language comes to an end, ceases to exist (for instance, recently, the Ladino language has practically disappeared in our plain sight). Usually, people speaking a vanishing language know another one, so that the vanishing language is no longer a necessary means of communication uniting all its speakers. And in these conditions every speaker provides words with his own particular meanings. Therefore the language disappears little by little. Something similar is happening today with theoretical semiotics.

- Nevertheless, would it still be possible to distinguish some directions of modern semiotics which seem promising in your view?

- First of all, linguistic semiotics: I mean, general linguistics, problems of general linguistics which are examined from a semiotic point of view. Then, I would say, the semiotics of culture, when cultural texts are approached from a linguistic point of view (we are entitled to speak about various "languages" of culture - e. g., language of art, language of rituals, symbolic languages, etc.). And also biosemiotics seems promising to me, even if I don't know much about those matters. Finally, semiotics of economics seems interesting.

- Speaking about linguistic semiotics, what problems, in your opinion, could linguistics solve by means of semiotics? 
- Linguists can use the notions of denotatum, form and meaning [denotat, forma, znachenie], from the well-known semiotic triangle. In my opinion, this triangle is in general one of the most important achievements of semiotics.

\section{- Is it possible to examine the origin of language as a semiotic problem?}

- Yes, undoubtedly, both in phylogeny and in ontogeny. I mean, in particular, the processes of language acquisition by a child. They are obviously based on imitation when the interaction of a mother with her child takes place: a child imitates his mother, and she, in turn, imitates her child. The child's speech activity begins with inarticulate sounds; it is called childish babble. Meanwhile, mothers quite naturally look for meaningful words in this babble. You cannot expect a child to pronounce meaningful words, but nevertheless, for his mother, it is quite natural to search for meaningful words in this babble and to repeat them and to make her child repeat them. It is a semiotic process: signs are created in the process of communication, as a product of communication like a communicational derivation; we have here something like a communication of self-adjusting organisms.

When a child is born, his mother begins to talk to him as to an adult. Her behaviour contradicts common sense and at the same time it is quite natural. Something very strange happens: the mother speaks to her baby, though the latter is evidently not capable of understanding what she says to him, because he does not know language and, of course, he cannot adequately understand the content of what is said. The mother's behaviour is absolutely irrational and, at the same time, it can be justified pragmatically: it is clear that if mothers did not behave in this way, if they did not act like this and if they took into account what their children understood and what they did not, children would never begin to speak. In this way, a language is taught and when a child finally masters it, the child finds himself to be separated from his mother, this time semiotically. This way, during the process of semiotic activity, relations between the participants in communication are established.

Of course, communication between a mother and her child takes place not only by means of language: facial expression and various sounds (emotional, imitational, etc.) play an important role, too. But even signs of this kind can become independent communicational signs, that is, conventional, arbitrary, controllable signs. For instance, the mother makes a smacking sound with her lips in order for her child to take her breast, but in another situation she can do the same thing in order to make the child turn his face towards her. In the latter situation, the sign is separated from its initial content, being transformed into a manageable instrument. Practically speaking, it becomes a linguistic sign. This way, children assimilate linguistic behaviour. 
- Don't you think that semiotics could help linguistics to define more clearly, at least, for certain models, the limits of language? Because in linguistics the present situation is not very rosy either: speaking about 'language', people can mean most different phenomena...

- Different phenomena, yes, that's true. But still they are not as different as in the case of semiotic notions. By 'language' one may mean speech activity or means of communication; one may mean language in general or a particular language. However, in linguistics all this fits in with an a priori nomenclature.

- In your book Ego loquens ${ }^{5}$ you speak, among other things, about deixis and its role in language formation. How would you describe the role of zoosemiotics in the context of the general problem of language formation or language origins?

- In my opinion, some parapsychological relations exist between a mother and her baby. A baby can understand his mother's reaction without words, like a dog understands its master. At the same time, the human being is a very imitating animal, it is in his nature to imitate. Not all animals are like this - though, of course, besides human beings there are other animals showing a faculty for imitation. In my opinion, both of these factors operate when a language is taught. A child repeats something after his mother and she smiles, she approves his behaviour, the child feels this and wants to repeat again and again. In her turn, she repeats what he says, correcting his linguistic behaviour, and this way they repeat each other. Dogs would behave similarly if they could imitate their masters' speech and if their masters sought to teach a language to them.

- Does it mean that in the case of animals, it is impossible to speak about these two factors at once?

- I don't know, maybe somewhere these two factors appear together, but it is already beyond my competence, I don't want to take the liberty of making too strong generalizations... But I think that these two factors taken together constitute a necessary condition to master a language.

- But is it really necessary to describe the relations between mother and her baby as parapsychological? Isn't it simply educating with praise?

- At least, a baby perceives his mother's approval. How it happens - I don't know. A mother can say different words, but her baby - like a dog - perceives one thing: her approval.

$5 \quad$ Uspenskij 2007. 
- You have already distinguished several directions of semiotics which seem particularly promising to you. Would it also be possible to speak about traditions in semiotics, in your view? For instance, as to linguistics in its current state, the notion of a tradition is not generally accepted, for it presupposes a particular closeness of the linguistic community. So what about semiotics? Are there French, Russian, Italian semiotic traditions?

- I don't think so. Of course, there is American semiotics, relating to Peirce. Peirce is much less popular in other countries than he is in America. But it is hardly possible to consider it a national tradition. French semiotics is leftist and very politicized. As to Russian semiotics... In the Tartu-Moscow school, we tried not to be connected with any kind of ideology.

- If we continue to discuss linguistic "traditions", your discovery of the first Russian grammar written in Russian was very important for its time - in fact, your work 6 opened a new era in Russian studies: the study of a whole grammatical tradition which existed before Mikhail Lomonosov. How did you find this grammar?

- By chance. It was also by chance that I became a Slavist. My sphere of interest was general linguistics and semiotics, these two disciplines are closely connected with each other. While working on semiotics, I became interested in the semiotics of painting and, first of all, in the semiotics of icons. The canons of iconic painting are very strict, hence icons constitute a much more gratifying material for a semiotic study than any other genres of painting. This brought me to Old Believers. I wanted to look at icons in their natural environment. Because, you know, icons should be looked at in candlelight, they seem so bright precisely because nobody examined them as we do today, under a bright electric light. In the churches of Old Believers ancient icons appear in their natural conditions. So I went to Old Believers, to their rather secluded community in Moscow, and unexpectedly I recognized that they had a particular pronunciation when they were reading and singing. At that time, I was not a Slavist, but I could still discern a peculiar result of the transformation of the former "yat" beginning I thought that all these people spoke the same dialect, that they all had come from the same area. But later I had another idea, namely that it could be a particular liturgical pronunciation which is used for reading and singing ecclesiastical texts. It turned out that I was right and I began to study this phenomenon. This presupposed, on the one hand, expeditions to Old Believers who lived in different localities and who had not been communicating with one another for two or three hundred years;

$6 \quad$ Uspenskij 1975.

7 The name of a particular phoneme represented by the letter "yat" from the old Cyrillic alphabet. 
it was important to prove that they kept the same system of pronunciation which had a supradialectal character. On the other hand, I began to study ancient treatises in phonetics. I thought that it was necessary to study all published and manuscript treatises on language. In the course of this work, I discovered the grammar which you have mentioned at the Department of manuscripts of the Library of the Academy of Sciences. It was not a grammar of the Church Slavonic language (which interested me very much at that time in connection with the pronunciation of Old Believers), but a Russian grammar.

- ...So the origins of your work on liturgical pronunciation ${ }^{8}$ seem clear now too. As to the author of the first Russian grammar written in Russian, it was Vasilij Adodurov...

- Yes, I think I managed to prove it. What is important is that it is the first Russian grammar written in the Russian language; in general, Russian grammars had existed before, but they had been written in one or another foreign language and were not intended for Russian-speaking people.

- Like Ludolf's Grammar', for instance...

- Not only Ludolf's Grammar, there were also others ${ }^{10}$. Although, of course, Ludolf's Grammar was much more complete than any other grammars. As to the most ancient Russian grammar we know today, it was written in English by Mark Ridley (who was Boris Godunov's physician) at the end of the 16th century. Therefore, Russian grammars were not so rare: it is clear that foreigners wanted to know Russian, they needed it, for example, for trade... Among them, there was Michael Groening's grammar, which was rather large and written in Swedish, published in Stockholm in $1750 .{ }^{11}$ I succeeded in proving that it was a translation of the Russian grammar which I had discovered in a manuscript version.

- Your discovery has radically changed the chronological presentation of the grammaticalization of the Russian language... How would you characterize the semiotic character of your own research in the domain of Russian culture, if we can, of course, use this expression? Were all your research in this field semiotically oriented?

\footnotetext{
$8 \quad$ Uspenskij 1968.

9 Ludolf 1696.

10 Cf. Uspenskij 1992.

11 Groening 1750.
} 
- Yes, I think so. For instance, I have written an article about Peter the Great ${ }^{12}$, in which I explain why Peter was reputed to be the Antichrist. It explains, by the way, why there were no mass protests against him: a revolution against the Antichrist makes no sense; at the same time, there were individual protests, and very audacious ones. I tried to show that Peter the Great and his contemporaries spoke using the same words with different meanings, as if they spoke different languages. I mean, languages were different, while the means of expression were identical. Peter the Great tried to use a proper language which he himself was creating. And he wanted Russians to speak this newly created language, but the people could not (or would not) communicate in it. This was a semiotic problem.

In general, one of the key directions in my research is the semiotics of history. For instance, when we read an ancient manuscript, we want to understand how it was interpreted at the epoch of its composition, in particular, how the author himself, as well as his contemporaries, saw it. The same thing happens when we study a historical text. Historical events can be caused by a whole series of reasons: economical, political, etc. But I am interested in the motives which guided the participants of these events, and it is a purely semiotic problem, to understand which cultural language they spoke. For instance, we know that if there is thunder, it is a physical phenomenon: lightning, an electrical discharge... But what is essential is not what we know, but what, for instance, people in ancient times thought about this. If they thought that it was the god Perun, they acted on their own premises, not on ours.

- How were you initially drawn to semiotics? Do you remember your first "meeting" with semiotics, when was it?

- When we were reading Saussure. When I was student, we read Saussure very carefully and discussed him, believing that it was the only correct approach to the study of language.

- In this case, why did you define it as semiotics and not as semiology? As to Saussure, he was discussing semiology...

- We defined it as semiotics without implying any opposition between semiotics and semiology.

- Besides, the word 'semiotics' at that time was already relatively widely used, in comparison with Saussurean times...

12 Uspenskij 1976. 
- Yes, indeed.

- Thus you first discovered Saussure and only afterwards - Peirce?

- Yes, exactly: first Saussure, then Peirce.

- What would you say about your own contribution to semiotics?

- I can hardly be a judge. I used semiotics as an applied discipline, hoping to solve some particular problems which seemed topical in one or another domain (for instance, studying a literary text, historical events etc.). In other words, I tried to do something in the domains of linguistics, study of literature and art, history of culture, history as such. Anyhow, it was not a contribution to semiotics; using semiotics, I tried to solve some problems which were not semiotic ones.

- Then, going back to linguistic problems and to linguistics in general, could you please tell us what directions of modern linguistics do you consider as most interesting and promising?

- Nowadays the achievements of structural linguistics are sometimes denied. Here is a typical example: Viktor Markovich $Z_{\text {hivov }}{ }^{13}$, my former pupil who later became a colleague, wrote an article against structuralism, with a typical title: "Parting with structuralism" ["Rasstavayas' so strukturalizmom"] ${ }^{14}$. But I don't quite understand why we should part with structuralism. The achievements of structuralism, first and foremost of the Prague school, remain important. Of course, there are now new directions which are first of all concentrated on pragmatics and on the functioning of language, on the attitudes of the speaker and the listener, on the problems of deixis. But it is hardly reasonable to deny the achievements of the past at every new stage. It is a childish reaction: linguistics must develop by accumulation and specification, not by negation.

- In the lecture that you delivered here at the Summer School you said that, at his time, Chomsky had destroyed general linguistics and that it did not exist any longer. But what was so special about Chomsky's theories that could call forth such a situation?

- First of all, the attitude itself to his theory, its elevation to the level of a dogma. When in 1957 Chomsky's book Syntactic Structures was published, this work seemed very

13 Viktor Markovich Zhivov (1945-2013), Russian philologist, specialist in history of the Russian language.

14 Zhivov, Timberlejk 1997. 
interesting. But afterwards generative grammar supplanted all other approaches, it literally filled linguistics. It seems to me that in America there was approximately the same attitude towards scientific leaders as in the Soviet Union. In the Soviet Union, the academician Vilyams ${ }^{15}$ was the main biologist, the academician Pavlov was the main physiologist etc. Like Chomsky in America.

- You knew Sebeok personally, didn't you? Could you please tell us a little about your relations?

- I cannot say we were friends with Thomas Sebeok, but I knew him well, Sebeok used to come round to my house... No, I'm exaggerating: he visited my house only once (in the 1970s). On the whole, I don't consider Sebeok to be a very original scholar.

- What is your point of view about the significance of his theories for the modern semiotics?

- I don't know, really... I think he was nothing more than a manager of science.

- And what is your attitude towards Umberto Eco's theories?

- For me it is difficult to say, because Umberto Eco's semiotics is in no way connected to linguistics. But he is a very nice person. It was long ago, in the 1960s, when he came to Moscow in order to meet us all, to get acquainted with us. And afterwards, in Italy, of course, I used to meet him too.

- Were you friends with Jakobson ${ }^{16}$ ?

- Yes, if one could call relations between people with such an age difference friendship; friendship presupposes an equality (of rights), but of course, our relations were those of an elder and of a younger person, although Roman Osipovich did everything he could in order to level this difference. We were on first-names terms, which, of course, was his initiative, not mine. When my elder son was born, he and Krystyna ${ }^{17}$ came to my place to see him; I was very touched by their attitude. Krystyna spoke Polish to my son (he was several months old) because it is natural to speak to a baby in your native language. We met many times in Moscow and once in Tartu (he participated in one of

15 Vasilij Robertovich Vilyams (1863-1939), Russian soil scientist and agronomist.

16 Roman Osipovich Jakobson (1896-1982), Russian-American linguist, literary theorist and semiotician.

17 Krystyna Pomorska (1928-1986), specialist in Slavic literature and literary theory, Roman Jakobson's widow. 
the summer schools ${ }^{18}$ ) and also in Warsaw, at a Congress of Slavists ${ }^{19}$. Finally, we were together in Georgia: he suggested that we go there together and I accompanied him on his tour of the country together with V. V. Ivanov, K. P. Bogatyrev ${ }^{20}$ (who was later killed by security officers), S. I. Bogatyreva ${ }^{21}$ and T. V. Gamkrelidze ${ }^{22}$.

\section{- When did you meet him?}

- If I am not mistaken, Jakobson arrived in Moscow, for the first time after a long break, in 1958 - to attend the Moscow Congress of Slavists. But at that time I was not in Moscow, I was a student and I had been sent by the University to Western Siberia to cultivate virgin lands (Soviet students are known to have been sent there often), which is why we didn't meet at the time. Then he came to Moscow in 1961 or in 1962, and afterwards he was there every year, he loved both Moscow and us very much - not only because we were Russians but also because we were not Americans... He didn't like America. So he regularly came to Russia till 1968, until the events in Czechoslovakia. Naturally, after that he stopped coming. And then he started coming back again.

Once, I managed to organize his lecture at Moscow University. It was an important event for the university, the lecture hall was full. I think it was in $1979 .$. But it was also an important event for Jakobson himself. Before this lecture he was at my home and I saw that he (an experienced lecturer) was very nervous. For him, only one university existed: Moscow University. He began to deliver his lecture and I saw how agitated he was. At the beginning his voice broke off several times (which was very strange to observe in the behaviour of an elderly professor who had been lecturing at various universities for many years), and suddenly his voice got stronger, he stood up, it was so admirable. But after that, problems began, not for myself, but for my colleagues, who were Communist party members (G. A. Haburgaev ${ }^{23}$, K. V. Gorshkova ${ }^{24}$ ) and who had helped me organize this lecture. I can probably consider Jakobson my teacher, though formally he was not.

\footnotetext{
18 In 1966.

19 In 1973.

20 Konstantin Petrovich Bogatyrev (1925-1976), Russian philologist, translator, specialist in German literature.

21 Sofia Ignat'evna Bogatyreva (b. 1932), historian of literature, K. P. Bogatyrev's wife.

22 Tamaz Gamkrelidze (b. 1929), Georgian linguist, orientalist, specialist in Indo-European linguistics.

23 Georgij Aleksandrovich Haburgaev (1931-1991), Soviet linguist, specialist in the history of Slavic languages.

24 Klavdia Vasil'evna Gorshkova (1921-2002), Russian linguist, specialist in the Russian language.
} 
- Was he your teacher in the sense that he passed on to you an aspiration for a "holistic approach" to the material that you study?

- In the sense of the general direction of thought, I would say...

- And besides, among your professors was also Louis Hjelmslev ${ }^{25}$... How useful was this for you? Did it influence you when you were working on your PhD thesis (and your book) on structural typology $y^{26}$ ?

- No, at least not directly. Especially because, as a linguist, Hjelmslev did not impress me much. I had read his works, even before my stay in Copenhagen. He was a man of the old school: sometimes he would deliver a lecture, sometimes cancel it or leave without notice and it was impossible to know whether he would be at the university or not. He was a very nice person. And the atmosphere was very agreeable in the Copenhagen Linguistic Circle. ${ }^{27}$

In my book Ego loquens I reproduce one of my conversations with Hjelmslev, but if you want, I can repeat it here. When I arrived in Copenhagen in 1961, I went to the Institute of Linguistics and Phonetics, which was an ancient two-storey building. They gave me a key and I could go there whenever I wanted, there was a library there, with books in open access, and sometimes I was there completely alone. Having found out when Hjelmslev was going to be there, I went up to him to introduce myself (officially he was my tutor ${ }^{28}$ ). I had brought him a book from Moscow with a translation of his work. At that time, he didn't know that they had already published his Prolegomena in Moscow, translated by Yurij Konstantinovich Lekomtsev. ${ }^{29} \mathrm{Hjelmslev}$ and I spoke English; I didn't speak Danish at the beginning of my stay. Should I tell you how interesting it was for me, to meet Hjelmslev? At the time, he was a legendary figure. But I think it was also interesting for him to make my acquaintance because he had never seen a Russian student, at least, not after the war. Hjelmslev began to recall the Russian scholars whom he had met in his time, and, in particular, he mentioned the name of Scherba ${ }^{30}$, I think that they had met somewhere in the Baltic countries, in Lithuania I think, where they had studied Lithuanian. And I decided to tell him

\footnotetext{
25 Louis Hjelmslev (1899-1965), Danish linguist, one of the principle founders of the Linguistic Circle of Copenhagen.

26 Uspenskij 1965.

27 See also Uspenskij 1962.

28 In English, in the original Russian text.

29 Hjelmslev 1960 [1943 (1953)].

30 Lev Vladimirovich Scherba (1880-1944), Russian linguist, lexicographer, specialist in phonetics and phonology.
} 
about the glokaya kuzdra ${ }^{31}$. At present, experiments like this (phrases created from non-existing words) are well known, but at that time it was a fresh and fascinating topic. If I am not mistaken, Scherba was the first scholar who made experiments of this kind a subject of scholarly research. I was aware that Hjelmslev knew Russian, to a certain degree. He told me that his knowledge of Russian was passive, but that he could definitely read in Russian. I reproduced Scherba's phrase and told him how Scherba had analysed it from a linguistic point of view. "Yes, and what is the problem?", asked Hjelmslev, manifestly waiting for an interesting continuation. I found his reaction strange. "Sorry", I told him, "Did you understand this phrase?" - "Yes I did", answered Hjelmslev, "Continue please". I was taken aback. The effect of my story was lost. "Sorry", I said cautiously, "But what did you understand, precisely?" At that moment Hjelmslev felt a lack of self-confidence. As I have said, his knowledge of Russian was passive and limited. Any native Russian speaker would have immediately understood that the words of this phrase were non-existing and artificially created ones, and it would have created an obstacle for his comprehension of the whole phrase. Hjelmslev did not know Russian well enough to understand that these words did not exist in the Russian language. Being a foreigner, he proceeded from the assumption that some Russian words could be unknown to him, and this circumstance did not give him any cause to doubt the existence of one or another word. "How did you understand this phrase?", I insisted. Slightly confused, Hjelmslev said unwillingly: "I thought that there was a big animal which beat another animal and which is now beating its baby animal. Is that not it?" In general, this perception corresponds to the associations which this phrase usually provokes in Russian-speaking people. Hjelmslev did not know the Russian language well enough to understand that there were no words in Russian, from which Scherba's phrase had been composed. But he knew the Russian language well enough to understand the general sense of this phrase. In other words, Hjelmslev knew Russian badly, and that is why he understood Scherba's phrase. And, on the whole, he understood it correctly.

- As to the Copenhagen structuralism, in your opinion, it has never existed, has it? Do you mean that Hjelmslev was there alone? But what about Brøndal or Uldall?

- There is an important difference between Hjelmslev and Brøndal ${ }^{32}$. As to Uldall ${ }^{33}$, he had died before I came to Copenhagen. Eli Fischer-Jørgensen ${ }^{34}$ was a brilliant figure

31 A reference to the grammatically correct but meaningless Russian language phrase Glokaya kuzdra shteko budlanula bokra i kudryachit bokrenka.

32 Viggo Brøndal (1887-1942), Danish linguist and language philosopher, one of the founders of the Linguistic Circle of Copenhagen.

33 Hans Jørgen Uldall (1907-1957), Danish linguist, worked on glossematics with Louis Hjelmslev.

34 Eli Fischer-Jørgensen (1911-2010), Danish linguist, specialist in phonetics and phonology. 
there, she was a specialist in phonology. There were also Paul Diderichsen ${ }^{35}$, Hans Christian Sørensen ${ }^{36}$ and Henning Spang-Hanssen ${ }^{37}$, all very good linguists.

\section{- But did they all work within the framework of glossematics?}

- No, that's the point. But they used to see one another. Of course, their research could contain some elements of glossematics, but it was not their corporate language which united all linguists who were present there. Linguists from different countries came there too, they delivered lectures. I remember particularly well the visit of Eric Pratt Hamp $^{38}$. Hamp wrote an enormous number of works, and almost each of them was no more than one page long. If I am not mistaken, he wrote neither books nor large articles. But all his works were thorough and interesting. Each of them solved some particular problems of this or that Indo-European language. He came to Copenhagen from Yugoslavia (now in Kosovo) where he drove around in a jeep, studying the Gheg Albanian dialects. His wife Margo was always with him. Hamp was a charming person. As to Hjelmslev, he soon died - but before his death he managed to publish a little book called Language [Sproget]. Once Hamp arrived in Moscow and made a phone call to me; I invited him to my place. We had dinner, got into a conversation and then Hamp remembered something and said: "By the way, our American ambassador or American envoy - wants to organize a party, a reception in my honour, at the American embassy. Wouldn't you like to come there, with your wife?" I said: "But they won't let us come!" - "Why not?" - "They won't let us come, that's all”. - "But would you like to be there?" - "I have nothing against it, but it is unrealistic. When is this party taking place?" - “Tomorrow”. I said: "Ah no, that's absolutely unrealistic". He answered: "Anyway, I shall tell them, at the embassy, that you agreed to come, and it will be their business, to organize this meeting". The next morning, they called me: "Mister Uspenskij? We are calling you from the American Embassy". After this, there was a silence in the receiver, all tapping apparatuses were tuning in... "We confirm that you are invited to the embassy, this evening". And indeed, some time later I received an invitation in my mail box. So my wife Galya ${ }^{39}$ and I went there. On that side of the Garden Ring - I mean, where Tchaikovsky Street is located, because it was not the ambassador but their envoy who had invited us, the American ambassador was not there at that time - people didn't go on that side of the Garden Ring at all at that time,

\footnotetext{
35 Paul Diderichsen (1905-1964), Danish linguist, specialist in syntax.

36 Hans Christian Sørensen (1911-?), Danish Slavist.

37 Henning Spang-Hanssen (1920-2002) Danish engineer and general linguist.

38 Eric P. Hamp (b. 1920), American linguist, specialist in some Indo-European languages (Albanian and Celtic languages, among others).

39 Galina Petrovna Korshunova (1937-1978), philologist.
} 
there were only police officers standing there, one after another. So we went. There were police officers standing. They were looking at us - we went on. More police officers. We went by. Finally, there was the last cordon. A police officer was there. My wife gave him her passport (although he did not ask her for it). The police officer examined it carefully from cover to cover, twisted it in his hands and gave it back to my wife. I showed him our invitation, but not my passport. He examined the invitation, too. He told us: "Please". We entered and suddenly found ourselves abroad. There was a little yard there, obviously they used every centimetre of space. In the yard there was a huge dustbin and, straight above it, a bar was suspended, evidently they had very little space there. Numbers of the entrance and of the floor had been indicated on our invitation. We went upstairs and saw some coats hanging on a coat rack directly at the stairwell, therefore we could take off our coats, too. We did it. And suddenly we had a wonderful feeling of freedom: We are abroad! We rang the doorbell and this feeling of freedom disappeared immediately, because it was a huge Russian woman with a tiny headdress and wearing a miniskirt who opened the door; obviously she was a KGB sergeant. "Welcome", she said with a broad smile. We felt ill at ease, at once. Afterwards there was a reception à la fourchette. From time to time, two maids appeared (who looked the same, hardly pleasant) in order to offer us the next course. One maid held a tray in her hands but it seems she was not authorized to speak. As to the other one, she could smile and announce a dish or a beverage: "Would you like cognac?" (a smile); "Would you like caviar?" (another smile); "Would you like anchovies?" (one more smile). "Ah," my wife said. "Anchovies! I have never eaten anchovies". The smile immediately disappeared from the maid's face and she said: "No, you have. They are on sale in our country". This way, she took my wife down a peg... But we have already digressed from linguistics.

- Finishing our "chapter" about Hjelmslev: some books on the history of linguistics where the Copenhagen school of structuralism is mentioned say that it was the narrowest structuralist direction, that it was impossible to limit the object of study any more...

- Yes, that's right...

- And how would you define structuralism in its connection with semiotics? Is it possible to consider structuralism as a part of semiotics?

- If you like, structuralism is a part of semiotics. But of course, all semiotics cannot be reduced to structuralism.

- You mean, they are related as a set and a subset... 
- Yes.

- If we discuss the history of semiotics, it certainly includes the Tartu-Moscow School which we have already mentioned today. In your lecture, you said that its participants had always aspired for exact methods, for the liberation from any subjectivism...

- Yes.

- But what kind of exact methods did you mean? Please give us some examples.

- It seemed that we could use some mathematical models such as graphs, for instance... But I think that the most important thing - of course, it was a kind of a natural-sciences romanticism - was not this, but our awareness of the limits of exactitude: we know this, but not that... Let it not be an exact science, but at least we understand to what extent it is not exact.

- However, what exact methods did you use?

- Well, for instance, statistical methods or modelling.

- Let us go back now to another of your previous statements, to your very interesting point of view on the evidence and explications in linguistics and in semiotics - you touched upon this question in your lecture... And you said that neither in linguistics nor in semiotics is it possible to prove anything, but only to explain...

- I think so, yes. Of course, your objection was convincing: yes, in a certain sense, Bopp ${ }^{40}$ had managed to prove the affinity of Indo-European languages, but, for instance, can we really exclude the influence of language unions? Zaliznyak ${ }^{41}$ says approximately the same thing in his book ${ }^{42}$. Yes, he seems to have proven that The Tale of Igor's Campaign is an authentic work and not a forgery, but, strictly speaking, why couldn't we also suppose that it was written by a genius who had understood the very essence of Wackernagel's law? Though, in my opinion, it would have hardly been possible.

- But this is also Zaliznyak's opinion, his proof is based on this...

40 Franz Bopp (1791-1867), German linguist, one of the founders of the historical and comparative Indo-European linguistics.

41 Andrej Zaliznyak (b. 1935), Russian linguist, specialist in the Russian language and its history.

42 Zaliznyak 2004. 
- Yes, indeed. That is how he proves it. But speaking about proof in general... If I understand correctly, when Lavoisier, following Lomonosov, discovered the law of conservation of matter, what did he do in order to prove it? He made more and more subtle experiments, but in fact we can never know if for an even more subtle experiment it would not turn out differently. It is an inductive proof.

- Therefore in natural sciences the situation is as bad as in human disciplines?

- Yes, it seems so. If absolute proof exists anywhere, they do in mathematics. Though, as far as I know, there are some mathematicians who think that even in mathematics they do not exist. For instance, if the properties of natural numbers can change after one particular element in the natural sequence - we don't know where - in this case, it is impossible to prove anything at all.

- But is it possible, in this respect, to speak about certain particularities of precisely semiotic disciplines?

- Semiotics studies virtual reality. Semiotics does not deal with truth as such.

- Do you mean that semiotics studies models?

- Yes, exactly. Or do you think that semiotics deals with truth?

- Well, we can speak about correspondences, about non-correspondences, or about more or less evident correspondences of models to real facts and phenomena.

- It seems to me that we can speak about convincing and non-convincing models. As to their correspondence or non-correspondence...

- Do you think that in natural sciences one can speak about the correspondence and noncorrespondence of models, while in semiotic sciences, one should speak about convincing and non-convincing models?

- It seems to me that in natural sciences one should also speak about the convincing and non-convincing character of models. But here I am afraid that it is not already in my field any more...

- Then maybe there exists nothing but models in all sciences in general, and researchers have nothing more at all? 
- Yes, maybe...

- And therefore we can only discuss whether these models are adequate or not... But does anything exist beyond the models?

- You know, as Mandel'shtam said, "He shapes experience from babble / And drinks babble from experience..." [On opyt iz lepeta lepit / I lepet iz opyta p'et...]

- However, it still seems that, in this respect, there is a difference between semiotics and natural sciences.

- What difference do you mean?

- The difference is that semiotics studies various forms of knowledge. It is knowledge about knowledge. That is why the object of semiotics is different from the object of natural sciences.

- Yes, I agree. But do you mean that there are no experiments in semiotics?

- Why not? Only the fact is that in semiotics it is impossible to repeat the conditions of any experiment, while in natural sciences one can repeat the same experiment several times.

- What kind of experiments do semioticians make?

- And what about linguists?

- For instance, experiments are possible in field linguistics.

- In the domain of applied linguistics, of course... As to semioticians, they study sign systems like linguists do, only these are particular sign systems. But if experiments are possible in linguistics, they are of course also possible in semiotics.

- No, but ... What kind of experiments can we make in linguistics? For instance, I ask a person who speaks a certain first language if it is possible to say something in one particular way, and not differently...

- Or, for instance, in psycholinguistics or in neurolinguistics, studying aphasia is very much based on experiments... 
- Yes, of course, but what has all this got in common with semiotics?

- For example, imagine somebody speaking one language, but changing the pronunciation, I mean, speaking as people usually do not speak... But these are experiments in order to find out how it influences, for instance, the understanding of what is said. That is in linguistics. In semiotics, for instance, they repaint a house, in a way that people usually don't do. And then they observe what happens. The situation changes... Why can't we call this an experiment?

- We can, of course... And yet I would say that experiments are not the main method used in linguistics nor is it in semiotics.

- That is already quite another story... If we go back now, once again, to the TartuMoscow School, during the last ten years, at least, some Moscow semioticians, the majority of whom have had a linguistic education, show interest in the study of proper nouns. They organize conferences and publish books of collected articles on this topic ${ }^{43} \ldots$ What is your attitude towards this kind of research?

- In my opinion, it is very interesting!

- What would you say about the methodology of some of them? Some Moscow semioticians are often blamed for using methods that are not scientific, that all this is no more than a kind of insight, some flashes of inspiration, like Saussure (who was keen on anagrams) felt in his time that somewhere in particular texts proper nouns were hidden or "encoded"... Of course, now we are not speaking about the historical research of Moscow semioticians, but precisely about their analysis of "hidden (proper) nouns" in literary texts: someone can see them, while others cannot...

- Yes, I think that from a methodological point of view the research of anagrams is doubtful indeed...

- In your opinion, by what conception or by what model of the linguistic sign are the Moscow linguists-semioticians guided in their research? Would it be possible to say that the authors of those works don't share the Saussurean principle regarding the arbitrariness of connection between the signifier and signified in linguistic signs? Because, in fact, if a particular meaning is looked for in a form, this connection seems no longer arbitrary indeed...

43 Cf., for example, Nikolaeva 2001, 2007 and 2010; Uspenskij 2003 etc. 
- No; however, in my opinion, linguistic signs are arbitrary.

- Do you mean, sign-symbols?

- Sign-symbols, yes. And later on, on their basis, secondary connections can appear, but it does not mean that linguistic signs are not arbitrary. As to the diverse research made on anagrams, I also find it rather questionable, but, on the other hand, sometimes there are some evident cases. Such cases can also be found in music; for instance, when Bach encoded his own name in notes. This reminds us of similar evident cases with verbal texts.

- Yes, it does... On the other hand, Moscow semioticians are sometimes criticized for their study of 'world models': such as 'the Slavic world model', 'Balkanic world model'44... Do you consider 'the world model' to be a reliable linguistic concept?

- Yes, the 'world model' seems to be a concept with which it is possible to operate. But "Balkanic" or "Slavic" models are already more doubtful.

- But in this case, how would you define a 'world model', if it is not by way of language?

- By way of language. But by way of one concrete language and not of Slavic languages in general.

- Therefore, all in all, you share W. von Humboldt's point of view on the existence of the "inner form of language" which somehow influences our perception of the world? Or, for instance, the Sapir-Whorf hypothesis?

- Yes, I do.

- Let us speak now about other possible precursors of the Tartu-Moscow School of Semiotics. In your work "Myth - name - culture" ["Mif - imya - kul'tura"] ${ }^{45}$ which you wrote together with Juri Mihajlovich Lotman, you discuss the so-called mythological thought as a very particular kind of thinking. When stating this, were you guided by some works which already existed at that time and whose authors expressed similar opinions? In particular, to what extent does your point of view correlate with Lévy-Bruhl's theories about "primitive thought" 46 ?

\footnotetext{
44 Cf., for instance, Tsiv'yan 1990 and 1999, etc.

45 Lotman, Uspenskij 1973.

46 Lévy-Bruhl 1910, 1922.
} 
- I think it does; that is, maybe, it does not correlate directly, but, anyhow, I have always appreciated his theories.

- It seems that some parallels can be found indeed. For instance, you say that mythological thought is not at all primitive in the sense of its simplicity: it is oriented towards the solving of rather complex problems. A similar opinion is also present in Lévy-Bruhl's works: the fact is that the so-called "primitive thought" does not disappear, but remains at all "stages" of the development of humanity...

- Of course, I had read Lévy-Bruhl and I think so had Juri Mihajlovich, and even if we could have said this ourselves, we had predecessors, of course.

- What do you appreciate the most in Lotman? What was his most important, most remarkable quality, in your opinion?

- Lotman's most important quality was, of course, his human charisma.

- Yes indeed. And also, maybe, the fact that, in his case, science was inseparable from morality...

- Yes, exactly.

- And if we take the Tartu-Moscow School in general, is it possible to speak about its influence on modern semiotics? Or is it nothing more than history of science, today?

- I don't know what modern semiotics is, I think it does not exist. That is why it is difficult to speak about any influence.

- Do you mean that everything happening today is a repetition of what has already taken place in the past?

- No, in my opinion, in semiotics as such - in theoretical semiotics - the situation now is catastrophic; I already said it at the beginning of our conversation.

- And, in your opinion, the way out of this difficult situation is possible only in unity, in finding a common language between different schools...

- I think that another way out can also be in using semiotics as an applied discipline, when primary importance is assigned to concrete problems which can be solved with semiotic methods. Then semiotics can be justified. 
- Indeed, it seems that in many lectures presented at this School no problems were raised at all.

- Yes, you are right.

- Still in linguistics, for instance, we have got accustomed to the fact that first we raise a problem and then we solve it. And here sometimes it was not clear where some lectures started and where they ended... There was also a lack of concrete examples in some lectures.

- But on the other hand, there were some quotations...

- It appears that, in order to avoid problems, semioticians must learn... how to raise problems!

- Yes, I think so.

- Thank you!

- Thank you.

\section{Part II. Additional questions on semiotics, as based on the book Ego loquens ${ }^{47}$}

For this interview, we had prepared 13 questions on which this conversation is based.

1.

- Boris Andreevich, how would you define semiotics, where are the limits of semiotics, in your opinion?

- I could define semiotics as a science studying signs, but this does not say much. The sign is something which has a form [vyrazhenie] and a meaning [soderzhanie] - but once again, to say so is to say very little.

47 Uspenskij, B. A. 2007. Ego loquens: Yazyk i kommunikatsionnoe prostranstvo. [Ego loquens: Language and the communicative space.] Moskva: Rossijskij gosudarstvennyj gumanitarnyj universitet. Numbers of pages in brackets in the text below are from this edition. 
- Therefore, your definition of the sign is a Saussurean one?

- Yes, it is. More precisely, I would define semiotics as general linguistics. I mean, there is linguistics and there is general linguistics, and besides, there is also general general linguistics, I mean, the most general linguistics [predel'no obschaya lingvistika], linguistics in the most general sense [lingvistika $v$ predel'no obschem smysle].

- Do you mean, "meta-general linguistics"?

- Yes, I do.

- In this case, linguistics constitutes a part of semiotics, doesn't it?

- Yes, linguistics is a part of semiotics.

- But do you mean here all linguistics, in general? And what about, for instance, the cases when it is a question of purely phonetic research, for example studies on the pitch of sounds or on fundamental frequency?

- If all these studies have something to do with meaning, and usually they do, then this is, of course, semiotics. And what has nothing to do with meaning is not semiotics.

- And if we take, for instance, frequency analysis in the study of texts? Let us say, studies of frequency of the use of a particular word in a text...

- I think that all this has to do with meaning, indirectly. For example, how do you distinguish the sound of language from the sound of a cough? Language sounds are meaningful, whereas the sounds of a cough are not. There are some sounds which we utter involuntarily, which are not meaningful and which we ignore when we speak.

- However there are cases when it is difficult to distinguish, for instance, an interjection as an element of language from an involuntarily uttered sound.

- Yes, sometimes it is. But some things will be meaningful and some things will not. Of course, in principle, even the sounds of cough can be meaningful. When I demonstrate something with my cough...

- For instance, when with coughing sounds you inform somebody about your presence, "Ahem. Ahem." 
- Yes. And then this is semiotics, of course, but not of the linguistic kind. And there are also some sounds which have nothing to do with meaning, and which we disregard; for instance, when we hear them recorded or when we listen to our interlocutor. It is the same with breathing, for instance.

- If we go back to interjections, when, in your opinion, is 'ah' an interjection and when is it an involuntary sound? What transforms 'ah' into a language element?

- ' $A h$ ' is an interjection because it is composed of phonemes, /a/ and /h/ (by the way, this interjection is a Gallicism in the Russian language, it is absent from dialects). And when we deal with an involuntary sound, we can only put it down very approximately, when, for instance, we reproduce the sound of a rooster as 'cock-a-doodle-do'.

- However, phoneme analysis will also depend on the researcher's point of view. If he wants to find phonemes somewhere, he will find them... Maybe it is precisely the point of view of the speaker which transforms an involuntary sound into an interjection? The speaker must have an intention...

- Yes, I think you are right.

- And where are the limits of semiotics, from your point of view?

- If signs are involved, then it is semiotics. And when signs are absent, it is not semiotics. But at the same time I don't understand well if, for instance, reflexes are signs or not.

- There exists a point of view that when a reflex has already been created and when it has become quite automatic, it serves as a code, but there is no semiosis in this, like in mechanisms... That is, originally it was a sign, but later, when it became automatic, it stopped being a sign and turned simply into a working code.

- I see. But this way you have answered the question you asked me yourself. Where there are signs, there is semiotics. And where there are no signs, there is no semiotics.

- But it is also possible to think that semiotics embraces phenomena which suppose automatism; that is, they are no signs as such, but they are, at the same time, products of semiosis. 
- I think that all these are scholastic questions. If it is possible to apply what you are talking about to a particular description, it should be done. If it is not possible, there is no need to apply it.

- How would you define the 'sign'? And where are the limits of the property of being signs [znakovost']?

- As I have already said, the sign is a phenomenon which has a form and a meaning.

- Would you consider living organisms, or their parts, as signs?

- But why is a living organism a sign? Of course, the late Sebeok said that everything was a sign, but this somewhat deprived his theory of sense.

- Do you consider that semiotics does not extend, for instance, to animate nature or to ecological systems?

- No, I don't think it does.

- Therefore, for you, in general, semiotics is limited by culture, isn't it?

- Yes, I think it is.

- But in this case, what is your attitude towards biosemiotics?

- Zoosemiotics is certainly a part of semiotics, one where animal communication is studied, among other things. Or is zoosemiotics not biosemiotics?

- No, of course, zoosemiotics is a part of biosemiotics. But it turns out that, speaking about zoosemiotics, you still distinguish signs, even if it is not a sphere of culture, is it?

- It is, first of all, a sphere of communication. But why wouldn't it be culture? Of course, it is not human culture. But why should we consider that people have a culture, but not ants?

- Do you think that where communication exists, there is culture too?

- Yes, of course.

- This means, for you, semiotics is directly connected with communication, isn't it? 
- Yes, it is.

- But in this case, however, animate nature will bear a direct relation to the notion of semiotics, because everything communicates in living nature, for instance, in an ecological system...

- Maybe, I simply don't know it. But what do you mean by "everything communicates"?

- Imagine animals, or even simple unicellular organisms, which move and which have the organs of movement...

- Do they have any choice in their behaviour?

- They have a choice in the sense that they have some kind of perception, which allows them to move in different directions - to the left or to the right...

- I simply haven't studied that and I don't know that. What you say seems to be anthropomorphism, that is, an attribution of our ideas about human communication to these simple unicellular organisms. If it is so, then of course, it is semiotics.

- It would be better to do without any anthropomorphism, here...

- But how is this possible, since we are humans? Can we study the communication of animals without anthropomorphism? I am not sure of it, especially as because, in my opinion, there has not been much progress in the study of animal communication. Of course, the language of bees, described by Karl von Frisch, does not resemble human communication.

- No, of course not.

- And I don't know if there is any choice in their communication, any free will. I mean, if sentences can be constructed or not, I simply don't know that. In your opinion, what is the fundamental difference between human communication and communication like the language of bees?

- In the language of bees there are no symbols.

- Do you mean, symbols according to Charles Peirce?

- Yes. There are icons and indices, but there aren't any symbols, that is, no pure conventionality. This seems to be the main difference. 
- Then, of course, all this is directly linked to semiotics. Semiotics is determined by communication, and when we speak about culture, the latter is also a derivative from communication. But of course, communication cannot be reduced only to human communication.

- Therefore, do you consider that the limits of the property of being signs [znakovost'] are also determined by communication?

- Yes. But communication can also imply the attitude of the one who sends a message to the one who perceives it, and sometimes it is possible that only the latter is present, while the sender of the message is absent.

- And autocommunication also exists... Of course, it is a particular kind of communication, too... But let us move on to the next questions. How would you define the 'signal'? Is the 'signal' the same thing, for you, as the 'performative sign' [performativnyj znak] (cf. pp. 103, 104-105, 145)? How would you define the 'symptom' (cf. p. 154-155)?

- In my book, I give the following definition of the signal (p. 103): "In contrast to linguistic signs, signals are not used for information exchange and therefore they are not intended for dialogue". I mean, there is no exchange of roles here. As to performative signs, they are not the same as signals. Indeed, performative signs can be used for dialogical communication. But when at traffic lights we see a red or a green light, nobody is expecting an answer in the same language from us. You simply see a green light and you drive. This way, you reply to this sign. But it is not a dialogue in the sense that you don't answer in the same language. As to the symptoms, I write the following (p. 154-155): "The signal of an animal is an expression of an affective state and of involving of other animals into it. It would be more precise in this case to speak about symptoms which are perceived as signals, rather than about signals".

- And how would you describe the structure of the linguistic sign and its meaning - for instance, that of a common noun - in the Indo-European languages (cf. p. 11)? Do you consider that non-individual connotations are a part of the structure of the meaning?

- Yes. I would say that the structure of meaning [znachenie] includes meaning [znachenie], denotatum and non-individual connotations.

- Therefore, here you pass from the Saussurean binary model of the sign to a ternary model, don't you?

- Yes, it seems so; I am sinning, yes... 
2.

- What are the bases and origins of your classification which divides signs into informative, performative and formative ones [informativnye, performativnye, formativnye] (pp. 50-53)? There are no references in your book...

- I have the impression that it was me who invented it, that is why there are no references.

- You know, we have found exactly the same classifications which already existed before, with the same terms: forma - informa - performa... For instance, in the book of Jan L. G. Dietz, Enterprise Ontology, published in 2006. As to your book, it was published approximately at the same time, in $2007 . .$.

- I haven't read this book by Dietz. As to my own book, I had written it earlier, of course. And I arrived at this classification independently, in the sense that I know neither Dietz's book nor its author. But it is possible that certain things were simply in the air... Besides, the notion of 'performativity' itself already existed before me likewise the words 'information' and 'form'. But I use these words in a slightly different way. For instance, regarding 'performativity', I understand the term in a broader sense than it is usually done.

- Isn't it possible, in this case, to consider the speech act theory which Searle and Austin have written about as one of the sources of your classification?

- You know, I haven't read them. I tried to do that, Searle first of all, but it did not seem so interesting to me. I can't say anything bad about him, he simply thinks differently somehow, not quite in a linguistic way, I would say. I only know the speech act theory by hearsay, and for me that was enough.

- Was Habermas among your sources? In his theories it is possible to find something similar, too...

- No. You know, sometimes I have the impression that, like Monsieur Jourdain, I speak in prose. Probably such things were simply in the air.

- You write in your book, for instance, that in mythological thought the pronoun 'I' will function as a proper noun (p. 61). It means that, in this case, 'I' and proper nouns belong to the same category of signs. However in your classification, they are put in different categories: proper nouns are a part of performative signs, while pronouns are formative 
signs. Therefore it turns out that your classification is not universal, but that it reflects a particular type of thought, a modern one. In this case, what classification of signs would you propose for a "mythological" type of thought? Or for other types of thought, which, in your opinion, it is possible to distinguish (if this is the case, of course)?

- The phenomenon of proper nouns seems to be basic for the definition of mythological consciousness. This does not mean, of course, that there are no pronouns in this type of linguistic behaviour. However, we can imagine a case when the pronoun 'I' turns out to be a proper noun - and therefore, it becomes the same category as proper nouns. An example of mythological consciousness is the thought of a child. Imagine that you are speaking to a child and, of course, you use the pronoun 'I' as a pronoun. At the same time, the child uses this pronoun as a proper noun and therefore he can say: "Don't you dare call yourself 'I', because it's me who is 'I"'!

- But how would you define the type of sign in this usage of 'I' by a child? Will this sign be performative or formative? If for a child it is a proper noun, it means that it is a performative sign. And, therefore this classification is not universal, it is not the same for all languages: in the case of the language of a child it will be different in the sense that the division of signs into various categories will not be the same as for the language of adults, where the pronoun ' $I$ ' will be in the group of formative signs.

- Yes, but at the same time, if we speak about language practice rather than about consciousness, the classification will remain universal, because there is a way in which we speak with children. In this classification, there exist various cells, but they can be filled differently; you are right.

- Does it make sense to distinguish other types of thought in addition to mythological thought?

- I don't know... Mythological consciousness is so important because it is present in the ontogeny, we all live through it... And, in a certain sense, we keep it forever.

3.

- In your book, you say that signals (like other signs which have no meaning) refer to concrete and isolated fragments of reality which exist irrespectively of other phenomena (pp. 104-105). However, by definition, any sign can exist only in a system. Would it be right, in this case, to speak about fragments of reality which are "isolated", rather than "connected with each other"? 
- Of course, by definition, any sign can exist only in a system. As to the signals - let us take, once again, the example of traffic lights. Here we have three possibilities: green, yellow and red lights. No, I don't maintain that the whole reality is reduced to these three possibilities (it is our language which embraces everything), but only one concrete situation. When I speak about a concrete and isolated fragment of reality, I mean a particular system of signals. However, within the framework of a concrete situation, of course, signals are not separated from one another, but are interconnected.

\section{4.}

- You also write about closeness [zamknutost'] when discussing the meanings of (in particular) linguistic signs (pp. 9, 10, etc.). But what do you mean by closeness, in this case? - because you know that new notions constantly appear in language; besides, as you say, "vocabulary is principally open, in language" (p. 220).

- I mean that we think, and that our thought is limited by the language which we use. We cannot overstep its limits - like in Gödel's theorem we cannot overstep the limits of a system of description. In language, all the words are interconnected, and the whole universe is covered by this totality of meanings. Of course, there exist other languages. We can overstep the limits of one particular language if we know another one - in this case our experience simply becomes richer. But, anyhow, we shall be limited by our language (or languages), in which we think and in which we perceive our world. Speaking about closeness, I mean that we cannot overstep the limits of understanding which is imposed to us by our language, in the broadest sense.

- In this case, speaking about closeness, do you understand the language as a system which must be closed, by definition?

- Yes. It is closed, but at the same time, it is not fixed. That is, it can grow and change, in general.

- You mean, in diachrony. And on a synchronic level, according to you this system is closed, isn't it?

- Yes, if we understand synchrony as static.

- As regards language and understanding, may we consider understanding to be primary, while language is secondary? That is, we understand something before we formulate it by means of language. Therefore, at first, there is an unconscious understanding, when other sign systems operate. 
- I don't think so. But what kind of understanding do you have in mind?

- Maybe, by intuition?

- But there is also comprehension, and in this case language is used, isn't it?

- Yes, when cognition begins to function, in the sense of reflection, of course, then language starts working.

- Yes. Of course, it is possible that there is something else, apart from that. But, in my opinion, it is not connected with comprehension. Maybe, as Kant maintained, we understand intuitively what is good and what is bad. It is a question of belief.

- And if one speaks about unconscious comprehension?

- Do you mean what Jung wrote about?

- Well, it is not necessary to reason precisely in his terms - but it seems that we should not exclude the existence of this domain.

- But we don't know anything about it.

- Why not? It is possible to try to describe this field - as it is possible to try to describe the knowledge and cognition of animals.

- You mean, for instance, reflexes? When, let us say, we hear some loud noise and we are frightened before understanding what has happened?

- Yes, for instance. Or when we look at a picture and recognize something, for example, some figures. This recognition, of course, is part of some primary sign processes. They take place much earlier than our cognition begins to function.

- Imagine that a man is drawn in a picture. Do you think that at first we understand that it is a man, then we become aware of this fact, and then language begins to function? Don't you think that even during a primary recognition of this man on the picture, we still pronounce, mentally, the word "man", for instance, in a stenographic way?

- And if we take some even simpler distinctions than 'a man - non-man', for instance, or our recognition of different colours? We distinguish various colours - in particular, 
our memory (which functions partly on an unconscious level) helps us, - even before we call them by their names. And of course, it is already a particular sign system, because arbitrariness is present.

- But where is the boundary between the conscious and the unconscious? Do you remember the story of a famous lecture at the Moscow Mathematical Society, which took place (or rather which didn't take place) in the early 20th century? At that time, the chairman of the Moscow Mathematical Society was Nikolaj Vasil'evich Bugaev ${ }^{48}$, Andrej Belyj's father. A lecturer had to give a talk on the following subject: "Do animals have consciousness?", and the chairman said: "Before I call upon the lecturer to speak, I would like to ask if somebody here knows what consciousness is. You, for instance, do you know?" - "No, I don't". - "What about you?" - "No, I don't know that". - "And you?" - "No". - "I adjourn this meeting".

5.

- In your book, the word smysl 'sense' is used in different meanings: it is, evidently, a synonym for osmyslennost' 'meaningfulness' ( $p .114$, etc.), and also an analogue of the word 'meaning', but already at the level of text (p. 99). How would you define sense on the whole, if it is possible to define it terminologically at all? Should we completely give up the term 'sense' on the level of particular words - for instance, in the opposition of the words' senses and meanings?

- In linguistics, I understand sense basically as a text phenomenon. But of course, it can also be a question of particular words, of words in contexts. Meaning is a phenomenon of language, like a word. But words in a text have - or can have - a sense.

6.

- In your book you introduce several criteria allowing us to maintain that texts are meaningful, that they have a sense. They are:

(a) a text has a sense "if all its significant components (words) can be considered as correlating with a certain situation. In other words, a text has sense if there is at least one context which is common for its significant components [But what do you mean by "significant components"? Is it the same thing as "categorematic words"? E. V., K. K.] If we cannot imagine such situation, the text, on the contrary, appears as senseless, we are not capabale of understanding it" (p. 114, cf. also p. 124);

48 Nikolaj Vasil'evich Bugaev (1837-1903), Russian mathematician. 
(b) a text (a sentence) becomes meaningful if "we mean that its content, in principle, can be a subject of discussion and that theoretically it can be estimated as true or false: we admit that a potential addressee, in certain conditions, can agree with its content or not" (p. 166);

(c) a text (a sentence) is meaningful if it is possible to translate it into other languages (p. 171);

(d) the grammatical correctness of a text (of a sentence) is a criterion allowing to affirm that it is meaningful (pp. 220-221);

(e) a text becomes meaningful thanks to the presumption that it is meaningful (pp. 170, 189 , etc.);

(f) a text is considered as meaningful if we admit that it is possible to "imagine a situation in which we could produce the same - or a similar, from our point of view - text" (p. 223)...

Among all these criteria, which one do you consider as the most important one?

- I think that the basic criterion is the connection with a particular situation: a text is meaningful if all its significant components can be considered as correlating with a certain situation, if there exists at least one context which is common for all its significant components (yes, 'significant component' is the same thing as 'categorematic word'). But at the same time, of course, it is impossible to cancel all other criteria. And it depends a lot on pragmatic tasks, to determine which criterion will be the basic one. For instance, if you are a translator, then, for you, it is the possibility to translate a text which becomes the criterion that the text is meaningful. If you are a native speaker of a language and if I want to understand you, then for me, once again, the most important will be the first criterion, the connection with a particular situation.

- As to the two last criteria, don't you think that they allow us to consider any text as meaningful, in general? In other words, joining the opinion of Putnam which you are quoting, "However wrong a sentence is, it is absolutely unreasonable to maintain that under no circumstances it can be uttered by a speaker and understood by a listener" (p. 132) (this concerns not only grammatically erroneous sentences, but also sentences constructed from non-existing words)?

- According to my brother ${ }^{49}$, for instance, there are no senseless texts at all. And he is almost right... But not quite, I would say. Of course, it is very difficult to give an example of a senseless text. But, I think, it is still possible to imagine texts, which it is impossible to make any sense of. For instance, we can rearrange the words or change the grammar... Here, for instance, is a senseless text: 'Adresat izvestnyh pri'.

49 Vladimir Uspenskij (b. 1930), Russian mathematician and linguist. 
- But, according to your first criterion, this text makes sense, because it is possible to imagine a situation which makes it meaningful. Imagine that you say to a child: "Repeat, please: 'Adresat izvestnyh pri'”. And the child says this, "Adresat izvestnyh pri”.

- But when we quote, of course, any text can become meaningful.

- Therefore it means that there is a certain level at which any text is always meaningful.

- Yes, Oxfordian theoreticians studied and played this kind of logic games.

- At the same time, one of your criteria evidently refers to the property of being signs [znakovost']: "It is the presumption that a text is meaningful which makes it sensible". That is, "meaningful" means everything which is considered as a sign or as a text.

- Yes, but here we already overstep the limits of the language, and I am interested first of all in language, in what is sensible in language.

7.

- In connection with the question of meaningful texts, we have already touched upon the problem of translation. As you say, "translation can be considered as a particular kind of communication. In the situation of translation the sender creates a text, while the addressee creates an adequate (from his point of view [our emphasis - E. V., $K . K$.$] ) text in another language. These texts are supposed to have one sense (it is an$ initial premise which, generally speaking, cannot be realized in practice)" ( $p$ p. 99100). But if, as you defined it earlier (pp. 98-99), the denotatum of the text is always a particular and unique situation which everybody perceives differently, wouldn't it be more correct to speak about an "initial premise which, generally speaking, is never realized in practice"? In other words, wouldn't it be more correct, in this situation, to speak about the impossibility of a (completely adequate) translation?

- What is essential is that, while translating, we proceed from the possibility of a completely adequate translation. Otherwise, we are not translating.

- But what do you mean by adequate translation, in this case?

- I mean when a translated text is basically the same as the original one, when the most important things are translated. Even if, strictly speaking, no adequacy is possible here, because if I translate, for instance, from Russian into English, then, afterwards, 
any person who will translate my English text back into Russian will not obtain the original text. That is why, anyhow, the adequacy will be only approximate. But when we translate, we act on the premise that a compromise is possible. That is, we proceed from the assumption that a back translation of our text will coincide with the original text. Here I can draw the following parallel: when I say something to you, I can, of course, consider that we all think differently anyway and, therefore, you will not understand me. But then it is time to become silent, as Wittgenstein advised (already after he had written his vast treatise...). And still, probably, if we speak to each other, we don't act on this premise, but we suppose that our interlocutor will understand the most important things. Once again, it looks like we are making a compromise. But the notion of compromise itself is not exact, the more so because, in the case of translation, the person making the evaluation is a translator himself. But such is the world in which we live: it is impossible to translate anything totally accurately, and, maybe, it is even impossible to express oneself totally accurately.

- The question will just be what constitutes this most important thing which must be preserved in translation. Imagine, for instance, an advertisement of a banking product connected with Finland, which in Russian sounds like this: "Genuine Finnish quality" [Nastoyaschee finskoe kachestvo]. In Russia, this advertisement would work well. Now, if you tried to distribute the same product in Switzerland translating this advertisement from Russian into, let us say, French, word for word, the advertisement would not work at all, because of the different connotations of the word 'Finnish', in Russian and in French.

- Of course, this is an example of a non-adequate translation. A good translator would translate it, for instance, as "Genuine Swiss quality", if the advertisement is intended for Switzerland.

- That is why, maybe, the question about what is the most important thing which should be retained by all means in translating remains open - along with the question about the adequacy of translation. All this is so interesting because Lotman, for instance, especially in his last works - wrote about the importance of the notion of untranslatability [neperevodimost']. According to him, untranslatability is present in any communication, in any translation. Where there is something meaningful, there is untranslatability present, partially. But speaking about adequate translation, you obviously mean another thing, something else.

- Yes, indeed. 
8.

- In your interview in Palmse you said that you had first discovered Saussure and only afterwards Peirce. Whose position - that of Saussure or of Peirce - seems to you more congenial, now? Reading your book can leave the impression that, regarding some questions, you are much closer to Peirce or, at least, that you are not so close to Saussure for instance, when you present the structure of a sign as a binary or a ternary one (p. 53); when you understand text as a complex sign (pp. 97-98); when you touch upon the subject of creating signs in communication, rather than using signs which already exist (p. 9), etc. At the same time, when you gave a definition of the sign earlier, you apparently did it "à la Sausssure". So on what conception of the sign are your works based on?

- The fact is that when I make a theoretical step forward, I don't reflect every time upon whether it will be according to Saussure or according to Peirce. Otherwise it would be impossible to work. It is exactly as though you asked me: "Do you eat more pepper or mustard?" I eat both pepper and mustard, I eat both meat and fish. And I digest all this, in one way or another... Even if, subjectively, I appreciate Saussure more - first of all, because he is a linguist and I understand what he says. As to Peirce, as a rule, I simply don't understand him. But he is not responsible for this, because during his life he didn't publish much (like Saussure, actually), with the exception of this simple classification which had existed already long before, already Augustine was familiar with it: I mean the division of signs into icons, indices and symbols. As to all the rest in Peircean works, I don't understand it, and the most important thing is that I don't understand in which context all this can be useful.

- They say, for instance, that in Peirce's works, the sign is presented in its development, while in the case of Saussure, this temporal dimension is absent.

- But how is it possible to use it in concrete researches - if, of course, we don't study Peirce in detail? As we have already seen, the sentence 'Adresat izvestnyh pri' makes sense, it becomes meaningful when quoted. In this case, Peirce also becomes meaningful if somebody studies his theories. But will he be meaningful beyond these particular studies?

- Here is an example of how Peircean semiotics can be "meaningful", or useful: it is possible, for instance, to differentiate between plants, animals and humans precisely on the basis of the Peircean classification: there is a level where we can speak only about iconic signs, on the next level also indices appear, and finally, on the third level, there are symbols. 
- I agree that this classification is a very good one. But Peirce wrote several volumes, while this classification occupies only half a page. And what do we do with the rest?

- But this classification is directly connected with how Peirce understood the sign process itself: it is also based on three stages.

- But are you interested first of all in his understanding or in your science? Are you interested in Peirce or in the truth?

- In any case, in any understanding, we deal with models. We construct models in order to understand language, culture and communication... We use models all the time.

- Yes, of course.

- As to these models, we take them from somewhere. For instance, there are Saussurean, Fregean, Peircean models of signs...

- But one can also create a model oneself, a model in which the approaches of Peirce and Saussure are combined. That's what I do. As to the ternary model, it can be found also in other works than Peirce's.

- Anyhow, your model is not a Saussurean model, even if in your definition of the linguistic sign you follow Saussure.

- Yes, that's right. But the times of Saussure were already so long ago!

- Therefore, in some of your works you find it more appropriate to base yourself on Peirce and in some other works, on Saussure... When do you go from Peirce to Saussure, and vice versa?

- I don't know... But I wouldn't say that it depends on my particular works, in one and the same work I can be guided by both of them (as, for instance, in the book Ego loquens).

- Speaking about the Tartu-Moscow School in general, in the initial period of its existence its participants wrote a lot about binary oppositions, which, in general, corresponded well with the Saussurean approach. However, later, in the 1980s, their intellectual evolution from binarity towards ternarity becomes evident. We can see this both in Lotman's works and in your own... And it is precisely this evolution, this deviation from Saussure which seems interesting. 
- Yes, all this is true. But we have never sworn allegiance to Saussure! Yes, at some point in my life, I read him and I liked him. So what? I have also read Jakobson and I liked him too. Sometimes I deviate from Jakobson, sometimes I follow him...

- Yes, but when diverging from Saussure, rather than going towards Peirce it was also possible to direct your intellectual steps, for instance, towards Greimas, towards a quaternary model.

- To tell you the truth, I don't know much about those matters and, in general, the models of signs are of little interest for me. I am interested first of all in applied aspects of semiotics, for instance, when I see, let us say, some historical problems which must be explained, I try to explain them. And if, for this explanation, Peirce has something to offer... But, no, I cannot even say that "Peirce has something to offer", because I read Peirce very long ago, it was still in my youth... But anyhow, I choose a model, let us say, a sign model which seems appropriate in order to explain one situation or another. And doing so, I never think whether it corresponds to Peirce or not. Yes, I have read Peirce, I have read Saussure and Frege, too... And afterwards, I digested them, and my works are a result of this digestion.

- We wonder when, in general, Peirce's ideas arrived in Russia. It is well known when Saussurean theories came there, but as to Peirce...

- I have known Peirce's works since my student years, but I probably read him in the original, not in translation.

- On the other hand, you discovered Saussure also when you were student - therefore you got to know their theories approximately at the same time, though Saussure had already been translated into Russian by that time and therefore they knew him better in Russia.

- Yes, of course.

- Did the participants of Moscow-Tartu School know Peirce well?

- They knew Peirce, of course, but only as far as it is possible to know him in general. And, in my opinion, it is impossible to know him, because he is very confusing. But, at least, I knew the classification which you were speaking about. 
9.

- In your book you say that one of the major functions of deixis (in particular, of personal pronouns) is to form a foundation to getting to know the objective reality (p. 41, etc.). And if we imagine a language in which there are no personal pronouns at all, what kind of thought will people speaking this language have?

- It is a difficult question. It seems to me that, theoretically, no languages can exist without personal pronouns. And at the same time it seems that sometimes one can observe something of this kind. If we take Japanese, for instance, there were and there are personal pronouns as such in this language, but they are so disguised by the forms of politeness that they seem to be already something else, not pure pronouns. Anyhow, they are not simple pronouns. I think that the situation is the same in some other oriental languages, for instance, in the Korean or in the Thai language. We can suppose that some people (maybe peasants) can use personal pronouns there on which the forms of politeness are less superposed. I am inclined to think that in such languages personal pronouns are present, so to say, on the onthological level - they are what is substituted by forms of politeness.

- Therefore, if we go back to your classification of signs, the distribution of signs in these languages, once again, will not coincide with the distribution of linguistic forms, let us say, in Russian?

- No, in the case if there are no personal pronouns in these languages (but I am not sure of it).

- Indeed, it is impossible to imagine a human language without personal pronouns - nor a language of animals with them. The fact is that personal pronouns need the presence of symbols which are absent in the system of animal communication: apparently if there are no symbols in the system of communication, deixis is simply impossible. That is, a monkey cannot say "I".

- No, I think it cannot.

- However it is interesting that, on the one hand, human language is precisely a language in which it is possible to say "I". On the other hand, the cultural evolution seems to lead to... no, of course, it does not lead to the language of monkeys, it is something completely different... 
- Yes, all this interested me very much, too. Something very interesting is, for instance, replacing the address in the second person by the address in the third person; like in German, for instance, they now say Sie, where they once said er. Is it like this in many languages - for example, in Japanese, too.

- There is, in fact, a renunciation of deixis...

- Practically speaking, yes.

10.

- In view of the problem of deixis, you also discuss proper nouns in your book (pp. 14-16, etc.). Among other things, according to you, "the difference between pronominal and non-pronominal deictic words corresponds to the difference between proper and common nouns" (p. 17); there also exist cases of assimilation of pronouns to proper nouns (p. 28). But may we ask you to provide an exact definition of what a proper noun is?

- Jakobson's definition suits me entirely.

- But is it possible, in your opinion, to consider this definition as universal - or, on the contrary, does it vary depending on the "type of thought" of a person or another? - if, for instance, you say that for a "mythological thought" the pronoun 'I' has the function of a proper noun (p. 61), while in English 'I' (associated with a proper noun) is capitalized (p. 82)?

- I think that it isn't the definition itself that varies, but its content - like the content of various categories of my classification, you are absolutely right.

11.

- In your book you write about a "particular sensitivity" [osobaya chuvstvitel'nost'] of the Russian language with regard to deixis. Do you think that, in this respect, the Russian language is special, in comparison with other Slavic languages?

- I don't know Slavic languages well enough to answer you for sure. Besides, it is also difficult to answer because the Russian language, unlike other Slavic languages, has less contacts - I mean, direct contacts - with other Western languages. That is why the Russian language can seem more conservative in this respect. But in general, of course, everything is changing. For instance, in my book, there is the following example: "I am so glad to see you!" - "So am I." And now even I myself would already 
agree that it is possible to say, in answer to somebody's "Ya ochen' rad Vas videt'?" "I ya tozhe" (earlier, it was absolutely impossible to say this!). Or another example which I give in this book: "Eat me". I have recently been to St. Petersburg and I saw there the following advertisement for some chocolate: "Poprobujte menya, ya sladkij" 'Taste me, I am sweet' (once again, in the past it was impossible to find such a signboard). As we can see, the Russian language is changing - undoubtedly, under the influence of West European languages.

- In your book, you give a similar example of an advertisement from an Italian marketplace.

- Yes. But some time later, I also found a similar example in Russia, though it is an evident borrowing... That is why what is written in my book bears direct relation to the time when I was writing it.

12.

- Your book Ego loquens which covers, as you say, the problems of language communication and which touches upon the questions of language phenomenology (p. 7), is divided into three large parts dealing, respectively, with (I) "Deixis and communication" and with (II, III) "Communication and understanding" ("How understanding is related to speech production" and "Understanding and linguistic experiments"). If you were asked to write a little conclusion to the whole book, one which would cover the conclusions to the three parts of your book at once, what would you write?

- I would formulate what this book is about in the following way: "In this book, I tried to explain how we understand text".

13.

- In your opinion, what united all the participants of the Moscow-Tartu School? What did they have in common?

- I don't know ...

- But did they have anything in common?

- Of course, they did... First of all, it was our unrestrictedness as to one particular profession, our interest in other domains, our intellectual openness. Secondly, our 
conviction that it was possible, to a certain - even if to a minimal - degree to come nearer to truth, as well as our certitude that truth is not mathematical. Besides, of course, we were united by our confidence in one another - I mean, first of all, our human confidence. And also, maybe, it was our interior "oppositional qualities" [oppozitsionnost'] which could not be reduced to being in the opposition, to being against somebody or something: we were against the regime problems in general.

- Would it also be possible to say that you were united by some common topics or notions? Were you united by the notion of semiotics, by the notion of culture?

- Yes, the notion of semiotics united us all, indeed. The notion of culture too - but that was afterwards, at the second stage.

- Thank you very much, Boris Andreevich!

- Thank you.

(Translated from Russian by Ekaterina Velmezova)

\section{References}

\section{B. A. Uspenskij's works}

Lotman, Juri M.; Uspenskij, Boris A. 1973. Mif - imya - kul'tura. Trudy po znakovym sistemam [Sign Systems Studies] 6: 282-303.

Uspenskij, Boris A. 1962. Lingvisticheskaya zhizn' Kopengagena. Voprosy yazykoznaniya 3: $148-151$.

- 1965. Strukturnaya tipologiya yazykov. Moscow: Nauka.

- 1968. Arhaicheskaya sistema tserkovnoslavyanskogo proiznosheniya (Iz istorii liturgicheskogo proiznosheniya $v$ Rossii). Moscow: Izdatel'stvo MGU.

- 1975. Pervaya russkaya grammatika na rodnom yazyke (Dolomonosovskij period otechestvennoj rusistiki). Moscow: Nauka.

- 1976. Historia sub specie semioticae. In: Bazanov, Vasilij G. (ed.), Kul'turnoe nasledie Drevnej Rusi (Istoki, stanovlenie, traditsii). Moscow: Nauka, 286-292.

- 1992. Dolomonosovskie grammatiki russkogo yazyka (itogi i perspektivy). In: Sjöberg, Anders; Ďurovič, L’ubomir.; Birgegård, Ulla (eds.), Dolomonosovskij period russkogo literaturnogo yazyka / The Pre-Lomonosov Period of the Russian Literary Language. (Materialy konferentsii na Fagerudde, 20-25 maya 1989 g.). Slavica Suecana, Series B Studies, 1. Stockholm: Almquist \& Wiksell, 63-169.

- 1994a. Izbrannye trudy: Tom I: Semiotika istorii, semiotika kul'tury. (Yazyk, semiotika, kul'tura.) Moscow: Gnozis.

- 1994b. Izbrannye trudy: Tom II: Yazyk i kul'tura. (Yazyk, semiotika, kul'tura.) Moscow: Gnozis.

- 1995. Semiotika iskusstva. (Yazyk, semiotika, kul'tura.) Moscow: Shkola "Yazyki russkoj kul'tury". 
- 1996a. Izbrannye trudy: Tom I: Semiotika istorii, semiotika kul'tury. (2nd ed.; Yazyk, semiotika, kul'tura.) Moscow: Shkola "Yazyki russkoj kul'tury".

- 1996b. Izbrannye trudy: Tom II: Yazyk i kul'tura. (2nd ed.; Yazyk, semiotika, kul'tura.) Moscow: Shkola "Yazyki russkoj kul'tury".

- 1997. Izbrannye trudy: Tom III: Obschee i slavyanskoe yazykoznanie. (Yazyk, semiotika, kul'tura.) Moscow: Shkola "Yazyki russkoj kul'tury".

- 2007. Ego loquens: Yazyk i kommunikatsionnoe prostranstvo. Moscow: Rossijskij gosudarstvennyj gumanitarnyj universitet.

\section{Other sources}

Bertolissi, Sergio; Salvatore, Roberta (eds.) 2010. Forma formans: Studi in onore di Boris Uspenskij. Vols. 1-2. Napoli: M. D’Auria editore.

Boyko, Taras 2017. Boris Uspenskij in English: Bibliography. Sign Systems Studies 45(3/4): 395403.

Chomsky, Noam 1957. Syntactic Structures. The Hague: Mouton.

Dietz, Jan L. G. 2006. Enterprise Ontology: Theory and Methodology. Berlin: Springer.

Groening, Michael 1750. Rossijskaya grammatika. Thet är Grammatica Russica, eller Grundelig Handledning til Ryska Språket; Jemte Et tilräckeligit Vocabularium, Ryska och Swenska Samtal, samt efter Ryska Språkets egenskap inrättade små Historier till öfning i Läsande. Stockholm: Kongl. Tryckeriet, Hos Directeuren Pet. Momma. [Cf. also in Unbegaun (ed.) 1969.]

Guan, Yue-e 2012. Boris Uspenskij and the Tartu-Moscow School of Semiotics. Chinese Semiotic Studies 7(1): 271-280.

Hjelmslev, Louis 1960 [1943; translated from the edition of 1953] [El'mslev, L.] Prolegomeny k teorii yazyka. In: Zvegintsev, Vladimir A. (ed.), Novoe v lingvistike, 1. Moscow: Izdatel'stvo inostrannoj literatury, 264-389.

- 1963. Sproget: En introduktion. Copenhagen: Berlingske.

Kull, Kalevi; Salupere, Silvi; Torop, Peeter; Lotman, Mihhail 2011. The institution of semiotics in Estonia. Sign Systems Studies 39(2/4): 314-342.

Larin, Boris A. (ed.) 1937. Genrih Vil'gel'm Ludol'f. Russkaya grammatika. Oksford, 1696. (Materialy i issledovaniya po istorii russkogo yazyka 1.) Leningrad: Izdanie Leningradskogo nauchno-issledovatel'skogo instituta yazykoznaniya.

Lepik, Peet 2013. Autorist. In: Uspenski, Boriss, Vene kultuuri jõujooni: Valik artikleid. (Lepik, Peet, trans.) 569-573.

Lévy-Bruhl, Lucien 1910. Les fonctions mentales dans les sociétés inférieures. Paris: F. Alcan.

- 1922. La mentalité primitive. Paris: F. Alcan.

Ludolf, Henrik Wilhelm 1696. Henrici Wilhelmi Ludolfi Grammatica Russica quae continet non tantum praecipua fundamenta Russicae Linguae, verum etiam Manuductionem quandam ad Grammaticam Slavonicam. Additi sunt in forma dialogorum modi loquendi communiores, Germanice aeque ac Latine explicati, in gratiam eorum qui linguam Latinam ignorant. Una cum brevi vocabulario rerum naturalium. Oxonii. [Cf. also Larin (ed.) 1937 and Unbegaun (ed.) 1959.]

Mazzali-Lurati, Sabrina 2014. Boris Uspenskij and the semiotics of communication: An essay and an interview. Semiotica 199: 109-124.

Nikolaeva, Tatyana M. (ed.) 2001. Imya: vnutrennyaya struktura, semanticheskaya aura, kontekst. Tezisy mezhdunarodnoj nauchnoj konferentsii, 1-2. Moscow: Izdatel'stvo Instituta slavyanovedeniya RAN. 
- (ed.) 2007. Imya: semanticheskaya aura. Moscow: Yazyki slavyanskih kul'tur.

- (ed.) 2010. Semantika imeni (Imya-2). Moscow: Yazyki slavyanskih kul'tur.

Pärn, Katre 2012. Tartu semiootika suvekool 2011. Acta Semiotica Estica 9: 264-266.

Podgorzec, Zbigniew 1978[1977]. Semiotics of the icon: An interview with Boris Uspenskij. (English, Christopher, trans.) PTL: A Journal for Descriptive Poetics and Theory of Literature 3: 529-548. [Translation of the text "Prolegomena k teme 'Semiotika ikony", Rossiya 3: 189-212, 1977. The interview was conducted by Zbigniew Podgorzec, on the occasion of the publication of Boris Uspenskij's book The Semiotics of the Russian Icon, 1976.]

Salupere, Silvi 2002. Semiootik Uspenski väisas vaimset sünnikodu. Postimees, September 13. Trunin, Mihhail 2016. “...takoe yavlenie prirody: utverzhdaet, chto Boga net, hotya sam kak angel”: Boris Uspenskij i Mihhail Lotman o semiotike i sovetskom nauchnom byte. Colta. $r u$, April $6 . .^{50}$

Tsiv'yan, Tatyana V. 1990. Lingvisticheskie osnovy balkanskoj modeli mira. Moscow: Nauka.

- 1999. Dvizhenie i put'v balkanskoj modeli mira. Moscow: Indrik.

Unbegaun, Boris Ottokar (ed.) 1959. Henrici Wilhelmi Ludolfi Grammatica Russica. Oxford: Clarendon Press.

- (ed.) 1969. Drei russische Grammatiken des 18. Jahrhunderts. Nachdruck der Ausgaben von 1706, 1731 und 1750 mit einer Einleitung von B. O. Unbegaun. (Slavische Propyläen 55.) München: Wilhelm Fink Verlag.

Uspenskij, Fedor Borisovich (ed.) 2003. Imenoslov: Zametki po istoricheskoj semantike imeni. Moscow: Indrik.

- (ed.) 2008. Miscellania Slavica: sbornik statej k 70-letiyu Borisa Andreevicha Uspenskogo. Moscow: Indrik.

Velmezova, Ekaterina; Kull, Kalevi 2011. Interview with Vyacheslav V. Ivanov about semiotics, the languages of the brain and history of ideas. Sign Systems Studies 39(2/4): 290-313.

Zaliznyak, Andrej A. 2004. "Slovo o polku Igoreve": Vzglyad lingvista. Moscow: Yazyki slavyanskih kul'tur.

Zhivov, Viktor M.; Timberlejk [Timberlake], Alan 1997. Rasstavayas' so strukturalizmom (Tezisy dlya diskussii). Voprosy yazykoznaniya 3: 3-14.

\section{Борис Успенский об истории, лингвистике и семиотике}

Высказывая свое мнение об истории и современном состоянии лингвистики и семиотики, в двух интервью Борис Успенский рассуждает о необходимости разработки общей рабочей терминологии для специалистов по семиотике, в то же время говоря о перспективах междисциплинарных исследований, о существовании разных исследовательских моделей и о принципиальных возможностях доказательств теорий в гуманитарных науках. Возвращаясь к уже написанным своим работам - в частности, к книге Ego loquens (2007), - Борис Успенский комментирует ряд важных событий своей академической биографии и делится воспоминаниями о встречах и контактах с коллегами, особенно подчеркивая значимость дружбы с Романом Якобсоном и Юрием Лотманом.

50 http://www.colta.ru/articles/literature/10671. 


\section{Boriss Uspenski ajaloost, keeleteadusest ja semiootikast}

Läbi kahe intervjuu esitab Boriss Uspenski oma vaateid semiootika ja lingvistika ajaloole ja praegusele seisule. Ta rõhutab vajadust ühtse semiootikaterminoloogia järele ning kõneleb interdistsiplinaarsete uuringute perspektiividest, erinevatest mudelitest ja tõestamisvõimalustest humanitaarteadustes. Kommenteerides oma töid, põhjalikumalt eelkõige raamatut Ego loquens (2007), kirjeldab ta ühtlasi olulisi sündmusi oma teadlaselus ning räägib kontaktidest Louis Hjelmslev', Roman Jakobsoni ja Juri Lotmaniga. 